accountability (Hunt), discussions about the values of codes of conduct (Edgar) and about the patient's best interests (Young), an appraisal of Noddings's 'feminine-feminist' theory on caring (Hanford), observations on and analyses of medical judgment and the right to die (Maclean) and nurse time as a scarce health care resource (Dickenson).

Each contribution deserves constructive critical appraisal which would go far beyond the limits of a review.

The twelve papers are backed up by a nine-page bibliography and a useful index.

More important is that the reader will feel challenged and stimulated; one of the best reasons for investing in the purchase of this lively, sometimes controversial, but always fundamentally sound publication.

RUTH A SCHRÖCK Fachhochschule Osnabrück, Federal Republic of Germany

\section{Self-interest and universal health care: why well-insured Americans should support coverage for everyone}

Larry R Churchill, London, Harvard University Press, 1994, 110 pages, $\$ 25.95$

In this slim monograph, Larry Churchill, Professor and Chair of the Department of Social Medicine at the University of North Carolina School of Medicine, sets out to infuse the debate about the form and financing [of health care] with the leavening of ethical analysis' and to produce an argument that will convince the American public that it should regard a health care system that ensures universal access to health care as essential. Churchill broadens the US debate about health care reform by considering the role of health care in society and argues forcefully that US health care policy should reflect not only America's familiar and dominant individual ethic with its emphasis on freedom and rights but also a strong communitarian social ethic.

A central theme of Churchill's book is his belief that health care policy should be viewed as a significant component of a nation's social policy and that as such it is an expression of the sort of society a nation wishes to have. The purpose of health and health care policy is therefore not limited to improving the health of individuals or the population. Indeed, Churchill argues that the primary goals of health policy should be providing individuals with 'security' (ie, 'freedom to live without fear that their basic health care concerns will go unattended and freedom from financial impoverishment when seeking or receiving care') and the nation with a sense of 'solidarity' (ie, 'the sense of community that emerges from acknowledgment of shared benefits and burdens'). The more familiar aims of improving the health of individuals and the population are regarded as secondary goals of health policy.

Americans' access to adequate, lifelong health insurance, even for those who are presently well insured, is precarious and the risks to physical, mental and financial well-being of not having adequate health insurance are great. Churchill argues that the goals of security and solidarity therefore reflect the enlightened self-interest of all American citizens. He draws heavily on the ethical and political philosophy of David Hume and Adam Smith to construct and support his arguments and he skilfully illustrates his points with anecdotes drawn, for instance, from his personal experience of the care offered by the British National Health Service. Churchill recognises that if the goals of personal security and solidarity are to be achieved health policy will have to reflect a communitarian and social ethic. $\mathrm{He}$ also recognises that as resources for health care are scarce, an equitable and just health care system that ensures universal access to care requires that society reaches broad agreement about the limits of care provided by the system, and that both users and providers of the service are 'judicious' in their demands for and use of health care resources.

I fear that Churchill's well argued views may not readily find favour in the present political climate of the United States. Nevertheless, by promoting a broader view of the role of health care in society, by drawing attention to the dangers of over-reliance on an individualistic, libertarian ethic and by appealing to enlightened self-interest, Churchill has produced a readable and valuable contribution to the health care reform debate. His views are of relevance beyond America and his readable monograph deserves a wide international audience.

NICHOLAS R HICKS

Department of Public Health and Health Policy,

Oxfordshire Health, Old Road, Headington, Oxford OX3 $7 L G$

\section{Proper use of human tissue}

Health Council of the Netherlands: Committee on Human Tissue for Special Purposes, The Hague, Health Council of the Netherlands, 1994, 141 pages, 50 DFL, publication number 1994/0IE

In 1991 the State Secretary for Welfare and Cultural Affairs of the Netherlands asked the Health Council of the Netherlands to provide information regarding current and future practices in relation to the storage and usage of human tissue with particular regard to the ethical and legal aspects. The Committee on Human Tissue for Special Purposes was convened, and its report and recommendations were published in a 140-page document in 1994.

The committee recognised that the main use of human tissue is in medical research and treatment and that the scope for its employment is rapidly expanding. Apart from the obvious uses in organ transplantation and transfusions is the use of tissue in teaching, further training, quality assurance, and the manufacture of therapeutic aids.

Whilst the moral justification of use of human tissue lies in social benefits accruing from therapeutic advances, the committee sought to address the potential moral deficits which may be associated with 'further use' of human tissue. The expression 'further use' refers to other purposes for which tissue is employed than those for which it was originally taken; for example, further research on existing tumorous material or future research on blood samples from screening programmes. Other examples would include the use of human cell cultures in biomedical science; tissue samples taken for diagnostic purposes which may lend themselves to epidemiological research. Thus new test results from old samples can generate new information about a disease. In one dramatic case in 1990 the application of new 